This year is a kind of anniversary for the Norwegian Polar Institute: its establishment can be traced back to Svalbard expeditions sponsored by Prince Albert I of Monaco in 1906 and 1907. In this unreviewed biographical article, biologist Eva Fuglei, who has spent many seasons on Spitsbergen (where her research has focused on Arctic foxes), and the editor describe part of the uncommon life of botanist Hanna Marie Resvoll-Holmsen, who

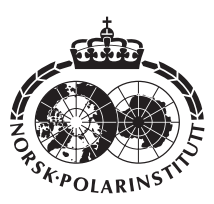
participated in the 1907 expedition.

\title{
Hanna Marie Resvoll-Holmsen: a pioneer in Svalbard
}

\section{Eva Fuglei \& Helle V. Goldman}

Norwegian Polar Institute, Polar Environmental Centre, NO-9296 Tromsø, Norway, fuglei@npolar.no.

In 1906 and 1907, a small group of Norwegian scientists participated in expeditions to the Svalbard archipelago organized and paid for by Prince Albert I of Monaco. Botanist Hanna Marie Resvoll-Holmsen - the first woman to carry out botanical research in Svalbard - went along on the 1907 expedition, returning the next year to continue her studies. Who was this woman?

On 11 September 1873, Julie Marie and Hans Resvoll had a daughter whom they named Hanna Marie. The couple's other daughter, Thekla, was older by two years. Thekla and Hanna would always be close friends and important sources of mutual support. They became interested in many of the same things, excelled in similar careers and even ended up marrying brothers. At the time of Hanna's birth, the Resvolls lived in Vågå, in mountainous southern Norway. Located along an ancient east-west travel route, Vågå derives its name from the old Norwegian word vega, denoting "travel". Hanna turned out to be a remarkable traveller indeed.

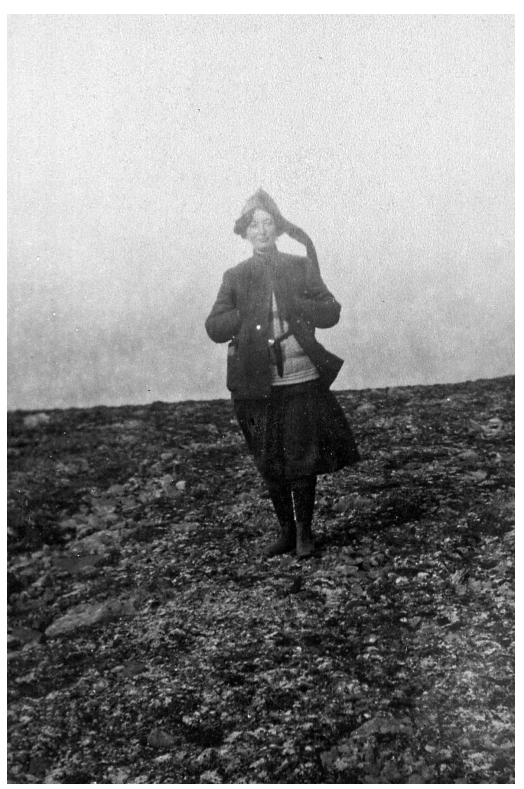

Hanna Marie Resvoll-Homsen, Svalbard, 1907. 


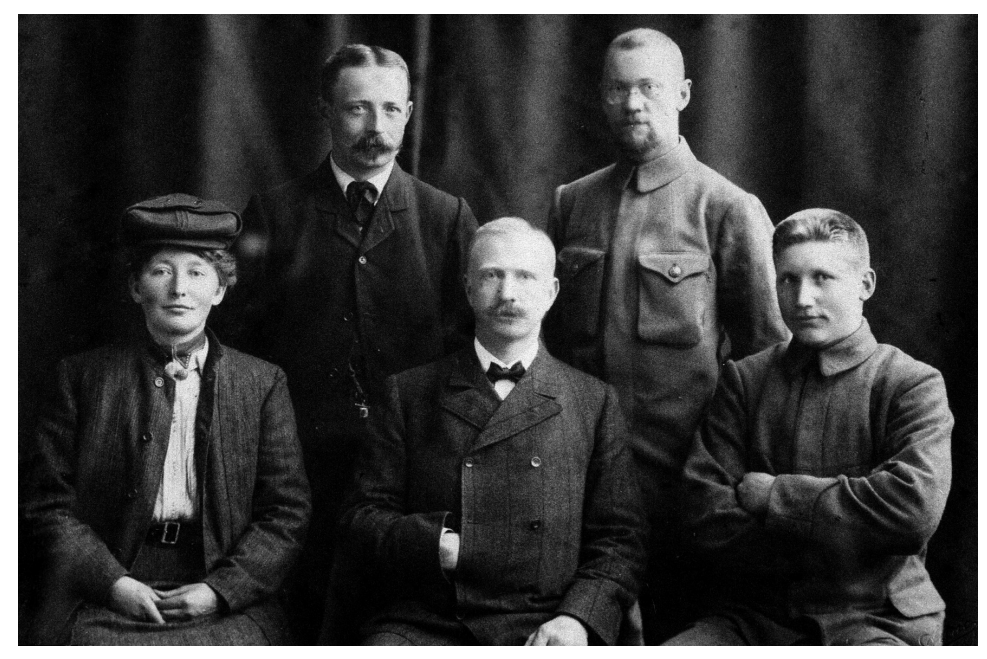

Formal group picture of the Norwegian participants of the 1907 expedition to Svalbard, sponsored by Prince Albert I of Monaco. Left to right: Hanna, Alv Strengehagen, Gunnar Isachsen, Adolf Hoel and Karl Jacob Haavimb. (Photo courtesy of the Norwegian Polar Institute Picture Library.)

The family moved to Kristiania, as Oslo was officially known until 1925, when the girls were small (Eckblad 1991). Though the family were by no means well-off-Hans had been bank-teller in Vågå and in Kristiania he was employed as a scribe for the Ministry of Justice (Christophersen 1943) - the girls' parents ensured that they were well educated. It must be borne in mind that in the late 19th century education was not freely available to everyone. Julie Marie in particular emphasized that her daughters would make something of themselves (Skår 2003), a conviction that both sisters would always keep with them. Hanna suffered an early setback when a childhood illness forced her to interrupt her education. The girl spent her time enjoying her mother's garden and reading books on a variety of subjects, including classic and philosophical literature and works in Latin (Resvoll-Holmsen 1927a). It was not until seven years later that, at the age of 19 , she could return to school. She passed the middle school examination just half a year later, proving that she had used her long convalescence at home fruitfully. In 1902, Hanna took the Norwegian equivalent of A-levels (latinartium) (Eckblad 1991). Following in her sister's footsteps (Thekla had taken her A-levels in 1892, just 10 years after these examinationsand thereby university education - were first opened to women), Hanna went on to study science and mathematics at Det Kongelige Frederiks Universitet, as the University of Oslo was called at that time.

In 1907, while still a student, Hanna participated as botanist in the expedition to Svalbard financed by Prince Albert I of Monaco. Some background is necessary here. Prince Albert had a strong interest in science, particularly oceanography, and was fascinated by the polar regions (Norwegian Polar Institute 2005). Beginning in 1898, he carried out a series of expeditions to 
Svalbard. The Prince's expedition of 1906 included a Scottish scientific group headed by William S. Bruce as well as a small Norwegian scientific delegation led by Captain Gunnar Isachsen, a topographer with military and Arctic experience. In 1907, the ambitious topographic, oceanographic, meteorological and geological investigations begun in 1906 were continued, again under the sponsorship of the Prince of Monaco. Two scientists joining the 1907 Norwegian team were geologist Adolf Hoel and botanist Hanna Resvoll-Dieset. (At 21, she had married a forest owner named Dieset; this unhappy marriage was soon dissolved [Chistophersen 1943].) According to Barr (1995), Hoel's backing was crucial for Hanna's participation:

Hanna was an atypical element...not just because of her gender, but also because of her field-botany-whereas the expeditions were mainly dedicated to marine and land mapping and geological investigations. Isachsen hadn't even considered botanical research in 1907, but he informed Hoel that he could attempt to obtain Mrs. Resvoll-Dieset the necessary tent and provisions if 1) she was extraordinarily clever, 2) her work in Svalbard would be of significant value, and 3) she was in possession of good practical sense and could be alone, if necessary all the time. (Barr 1995: 66-67; translated by the authors.)

Hoel, who greatly admired Hanna (Evjen 1999), could evidently assure Isachsen that she satisfied all his requirements. Being alone was no hardship for Hanna during the expedition. She would be put ashore with her tent and provisions

Left: Prince Albert I of Monaco (1848-1922). Right: His descendant, Prince Albert II of Monaco, visiting Spitsbergen in 2005. Kim Holmén (left) and Geir Wing Gabrielsen, two Norwegian Polar Institute scientists, accompany the monarch. (Pictures courtesy of the Norwegian Polar Institute Picture Library.)
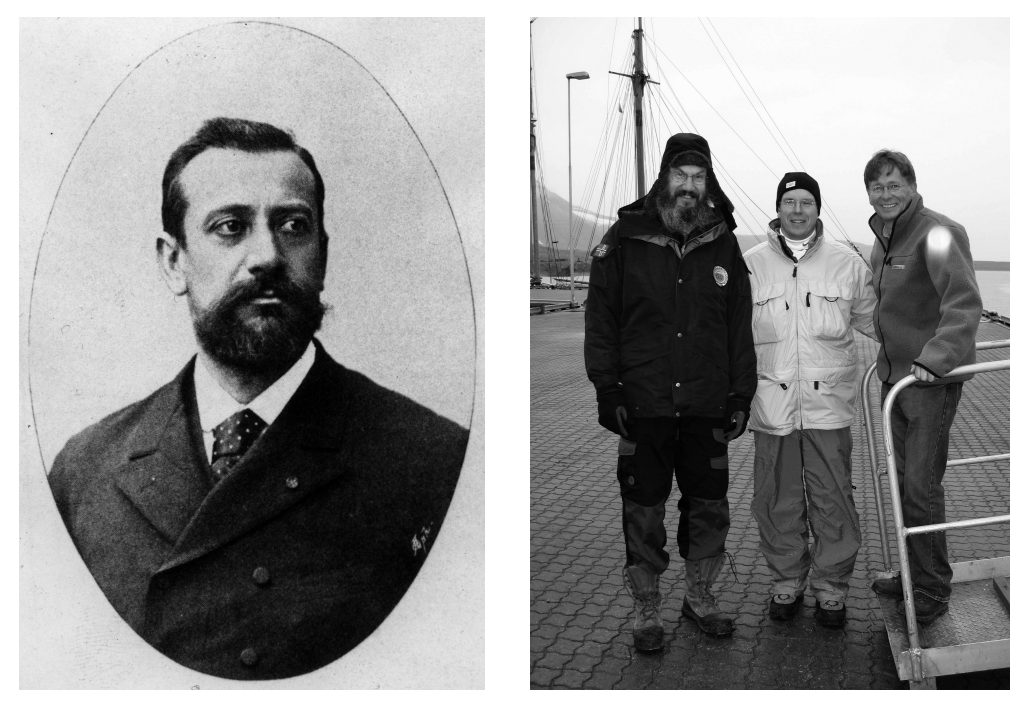


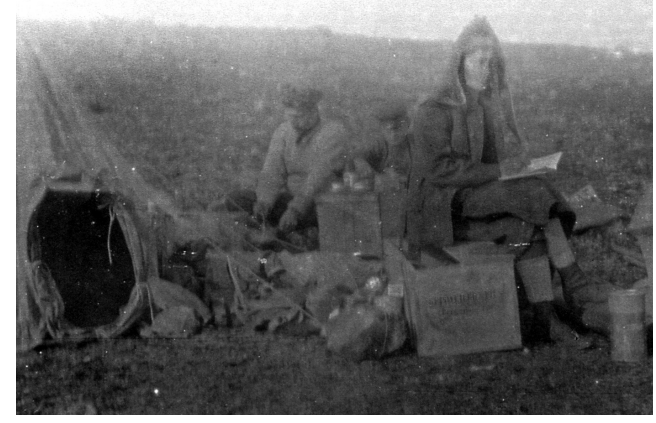

Hanna, Svalbard 1907. (Photo courtesy of the Norwegian Polar Institute Picture Library.) at some remote location on the coast. Days later, the ship would come to pick her up and then she would be deposited another place. Hanna thrived on the solitude and was extremely productive. During 1907 and more fieldwork the following year, Hanna mapped a great deal of the vegetation on the western side of Spitsbergen, discovering several new species and laying the foundation for much subsequent work on the archipelago's plant communities.

Prince Albert's expeditions of 1906 and 1907 led to important developments for Norway as well as internationally (Barr 2003). They spurred the Norwegian government, and private Norwegian investors, to fund Norwegian scientific cruises the following years. These expeditions evolved into The Norwegian State-Supported Spitsbergen Expeditions (De Norske Statsunderstøttende Spitsbergen-Ekspedisjoner), which in 1928 became institutionalized as Norway's Svalbard and Arctic Ocean Survey (Norges Svalbard-og Ishavs-undersøkelser). Adolf Hoel, a driving force behind the state backing of scientific research in Svalbard, was the organization's first director. The political ramifications of Norway's growing state-sponsored presence in Svalbard were enormous. Since its discovery,

Hanna at Krossfjorden, Spitsbergen, in 1907. (Photo courtesy of the Norwegian Polar Institute Picture Library.)

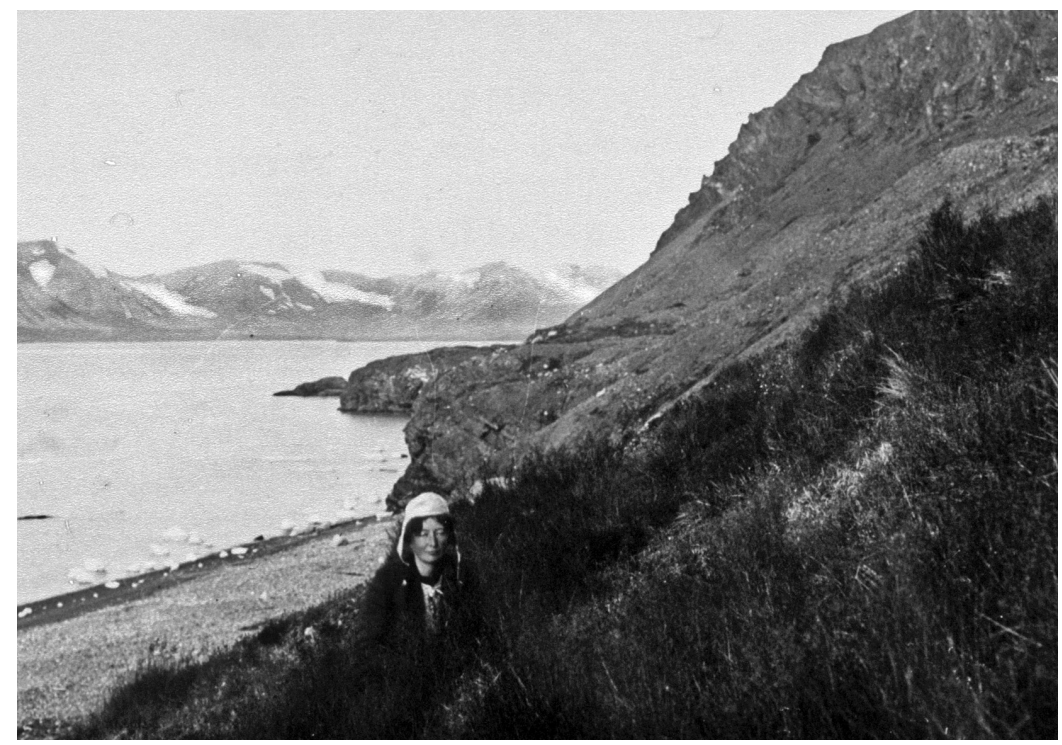


Picture taken aboard the Kvedfjord during the 1907 expedition to Svalbard. (Photo courtesy of the Norwegian Polar Institute Picture Library.)

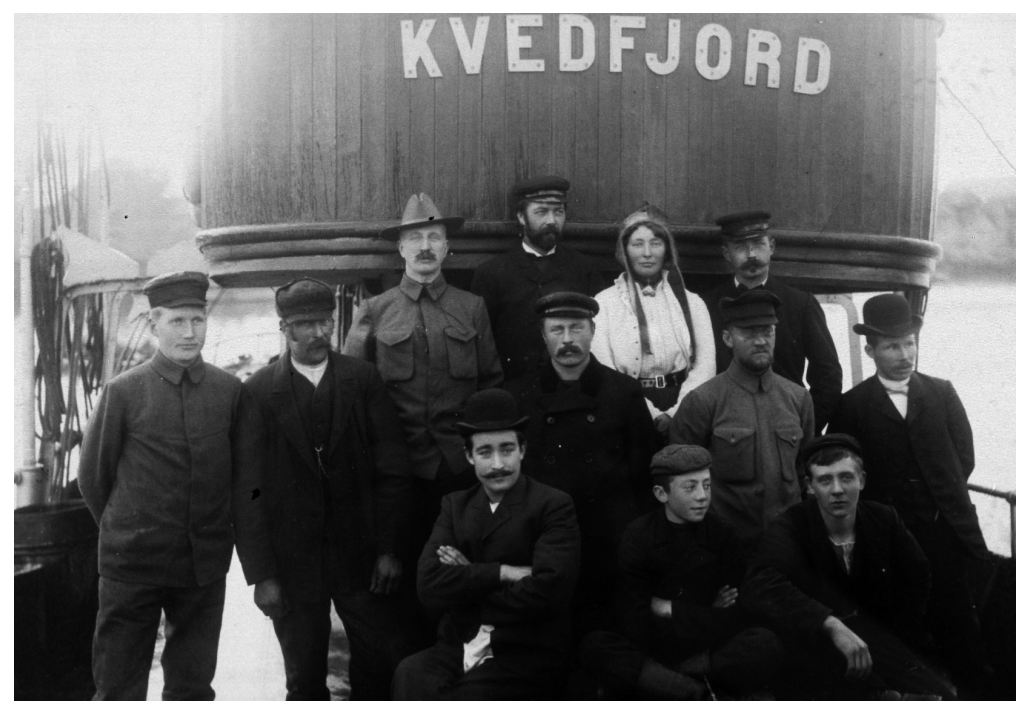

Svalbard had been a no-man's land or, more accurately, an "everyman's land" (Barr 200: 59): commercially exploited for its natural resources (whales, pelts and, latterly, minerals) and, more recently, investigated by scientists of many nations, but under the sovereignty of none. Spear-headed by Norway's scientific expeditions, Norway's increasingly visible footprint in Svalbard culminated in the international recognition of the country's privileged position with respect to the archipelago, as codified in the so-called Svalbard Treaty of 1920 (Royal Ministry of Justice 1988; Barr 2003). With a mandate expanded to include Antarctica, Norway's Svalbard and Arctic Ocean Survey was renamed the Norwegian Polar Institute in 1948.

Hanna on the left and Adolf Hoel on the right, Spitsbergen, 1907.

(Photo courtesy of the Norwegian Polar Institute Picture Library.)

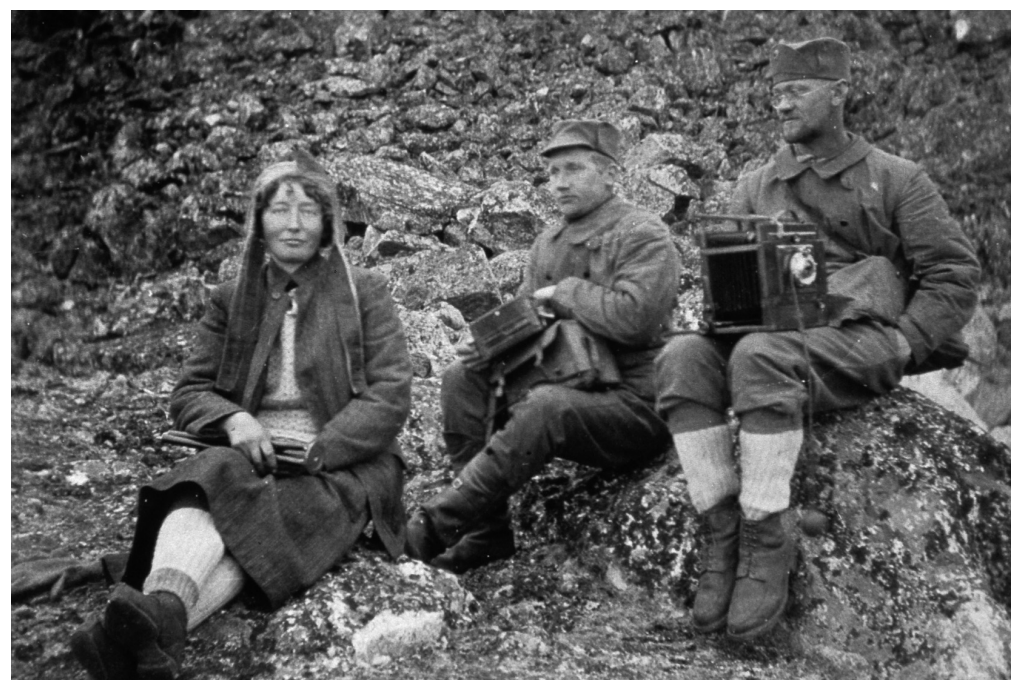




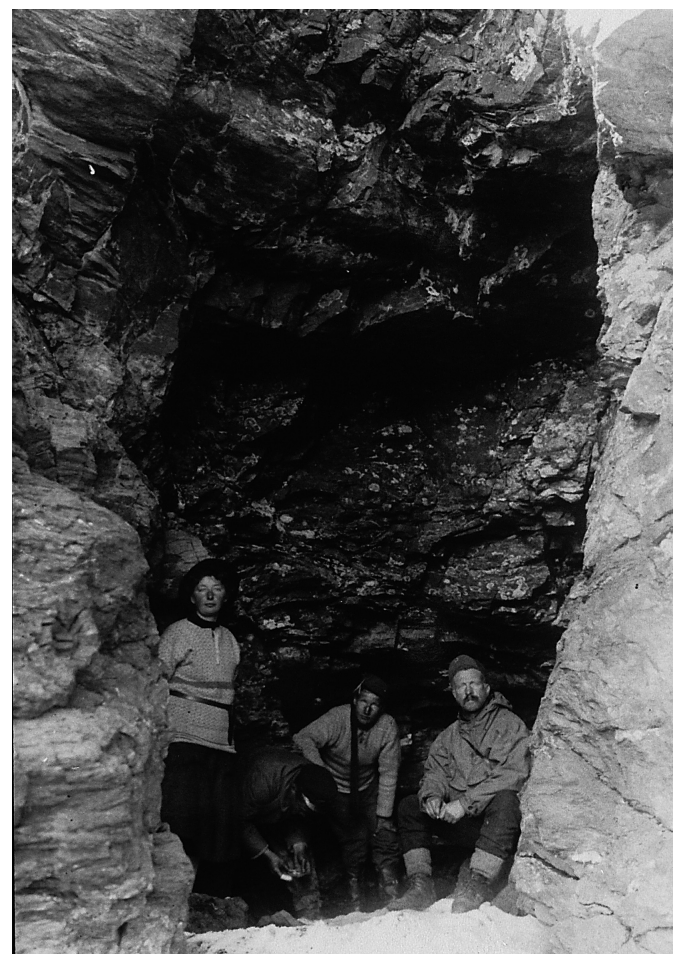

Exploring a cave on Blomstrandhalvøya, Spitsbergen, 1908. (Photo courtesy of the Norwegian Polar Institute Picture Library.)

Hanna found her own funding for further work in Svalbard in 1908, though she was able to take advantage of the transport offered by the Norwegian team of Prince Albert's Spitsbergen expedition that year. Additional members of the expedition included Gunnar Holmsen, a geologist, and Hjalmar Johansen, Fridtjof Nansen's partner in a legendary bid for the North Pole in 1895. Hanna's expenses were partly covered by the newspaper Aftenposten, which published her travel letters. These

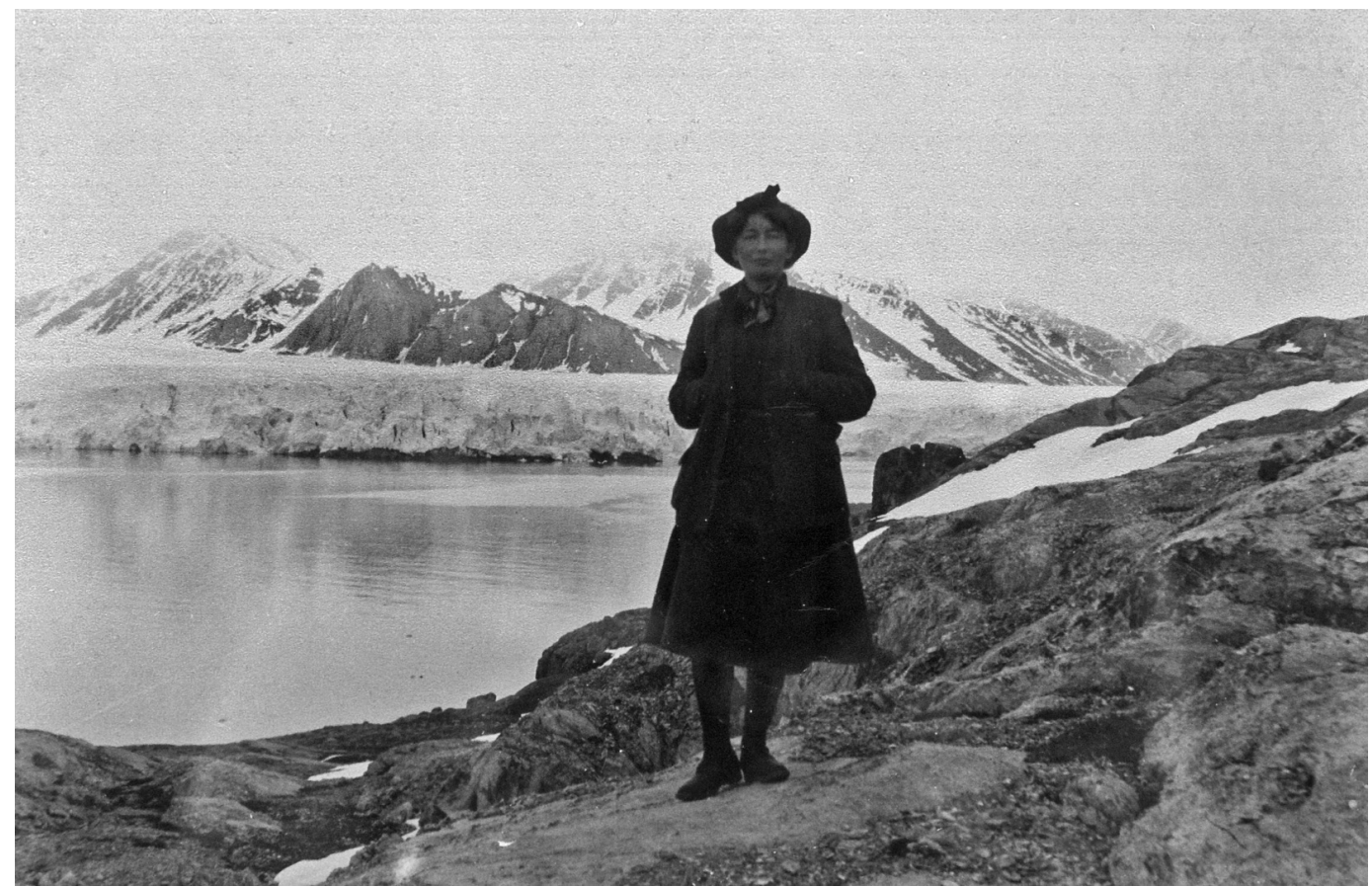

Hanna at Krossfjorden, Spitsbergen, 1908. In the background is the glacier Lilliehöökbreen. (Photo courtesy of the Norwegian Polar Institute Picture Library.) 
Hanna between Gunnar Holmsen and Hjalmar Johansen during the 1908 expedition to Svalbard. (Photo courtesy of the Norwegian Polar Institute Picture Library.)

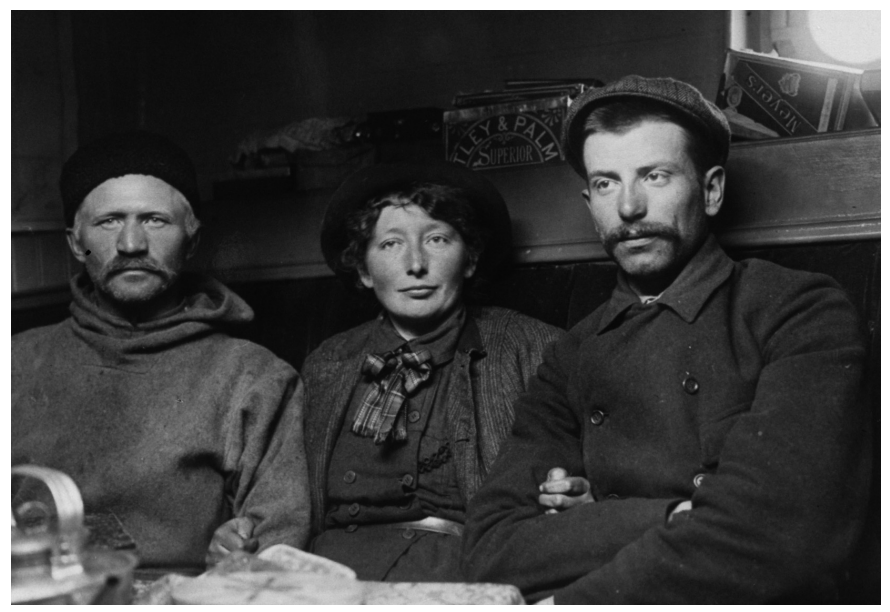

lively missives describe in detail the field conditions Hanna experienced. They also yield insights into the correspondent's special character: this was a person who could not have been better suited to this kind of fieldwork. In a letter dated 10 July 1908, written at Colesbukta (Cole Bay), Hanna wrote:

I didn't get to stay alone in my tent here in Cole Bay, as I had intended. 2 coal workers live in the bay in a turf hut, a Norwegian and a Finn. They are very amiable but are so sorry for me because I am alone. I assure them that it is my dearest wish for the moment, but they can't understand it. If they don't see me in the valley for a couple of days, the Finn comes, offering as his excuse: "We thought you were dead."

...Time passes far too quickly. Tent-life is wonderful. One sleeps when one is sleepy and doesn't think about what time of day or night it is. I go out mostly at night. One is aware that in just six weeks the nights will begin to darken, and that will be the end of this life... A better summer than by the protective fjord arms of Isfjorden is hard to imagine. One awakens, stretches and sticks one's head through the door to check the weather. If it's sunny, it's the height of earthly splendour; but it's also pleasant if it's overcast. Then the Primus is fired up, and one selects from one's stores depending on what one feels like. If it's cold, Thorne's tins are excellent, especially something with fat in it. It's funny how one comes to love anything fatty...After the meal, one prepares to go out, setting off without giving a thought to when to turn back again. (Schibsted \& ResvollDieset 1998: 47-48; this and following excerpts from Hanna's letters translated by the authors.) 
In a subsequent letter from Colesbukta, Hanna wrote:

...one can walk around in the fog and it's alright, at any rate when one is collecting plants. And when, soaked and tired, one finally returns to the tent, and the Primus is hissing while one eats one's food or presses plants, then one feels so snug and cosy.

Below the tent the waves beat against the beach, and the birds call, and big flocks of fulmars and kittiwakes fly over the tent, heading home to their bird cliffs...The wind rattles the tent sheet...the rain lashes the roof. After finishing work, one gets into one's sleeping bag, tilts the Primus to light up the dark tent, reads in bed a little while and sleeps a long, secure sleep. (Schibsted \& Resvoll-Dieset 1998: 51-52)

Hanna described her encounters with a representative of Svalbard's fauna in her letter from Sassendalen on 6 September 1908:

The frost has held since the 20th of August; all the streams have been frozen over since then. The Arctic fox has clad itself in its white winter suit. I have seen it several times up in the scree hunting the little snow bunting, Spitsbergen's only songbird. In areas where trappers occupy almost every bay during the winter, the foxes have become familiar with man's sinister intentions. One can't approach within 500 or 600 metres of them. This is very different than what I experienced last year on the north-west coast, where the fox would stand, eyes full of wonder, in the tent opening while I pressed plants, or it would give me a friendly jab on the head when it reckoned I had overslept. (Schibsted \& Resvoll-Dieset 1998: 61)

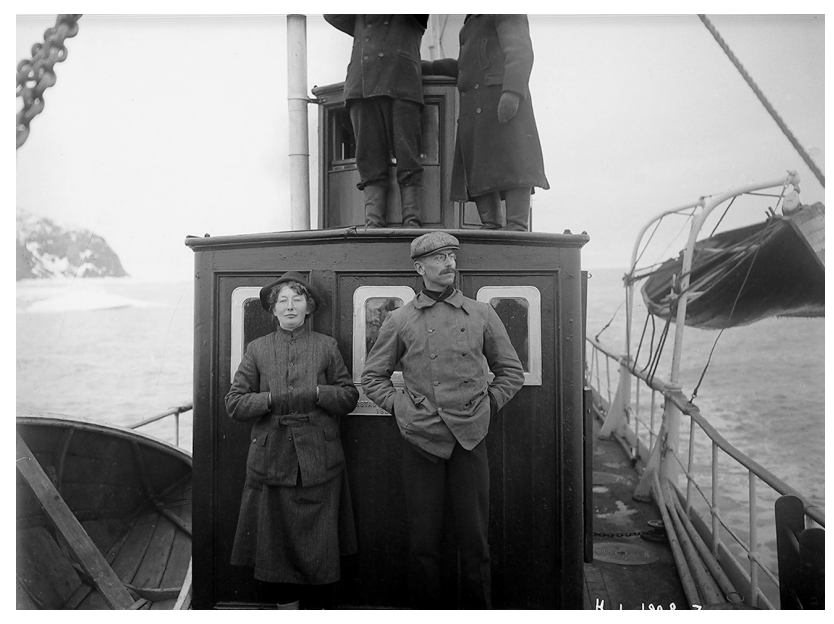

Hanna and Gunnar Holmsen aboard the Holmengrå, Svalbard, 1908. (Photo courtesy of the Norwegian Polar Institute Picture Library.) 


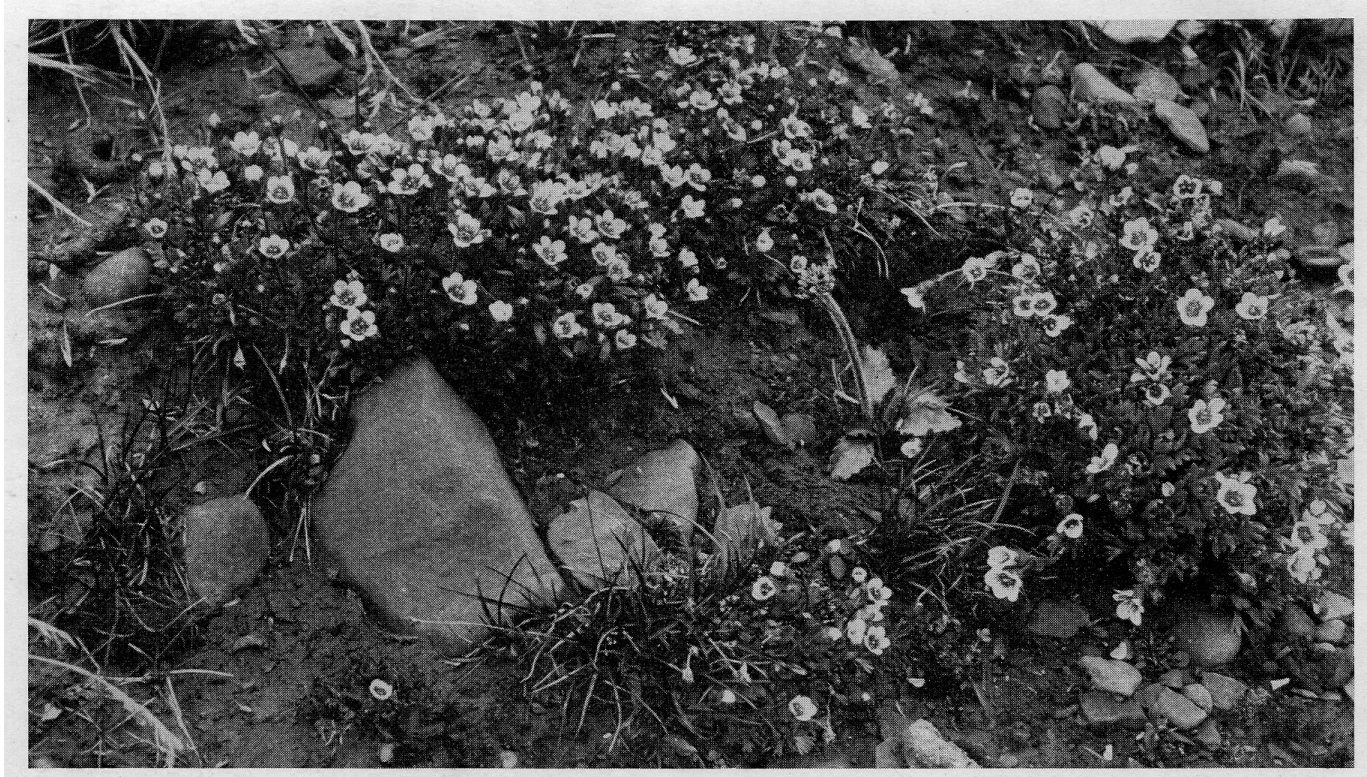

Fjellmark med tuesildre og i midten en snesildre

Tufted saxifrage (Saxifraga cespitosa) and, at center-right, a single alpine saxifrage (S. nivalis), one of many of Hanna's photographs illustrating Svalbards flora (1927b).

The work that Hanna depicts in these idyllic terms was not without its hazards, as she recounted in another letter:

The fog came and went, and soon the snow began to fall; it was the 16th of August, and since then the snow has covered the mountaintops in white. During my descent, when I was making my way over the northern stretch of an enormous glacier, I slid with my heavy load of fossils...Because of an earlier rainfall, followed by a frost, the snow crust was smooth as glass and my crampons could not get a purchase...My hammer, which I just happened not to have put away in my backpack, saved me...I hacked my hammer into the snow, dug in my crampons with all my might and threw myself onto the scree. (Schibsted \& Resvoll-Dieset 1998: 58-59)

Hanna and (probably) Gunnar Holmsen enjoying the snow at Heerfjellet, on the eastern side of Grønfjorden, Spitsbergen, 1908. (Photo courtesy of the Norwegian Polar Institute Picture Library.)

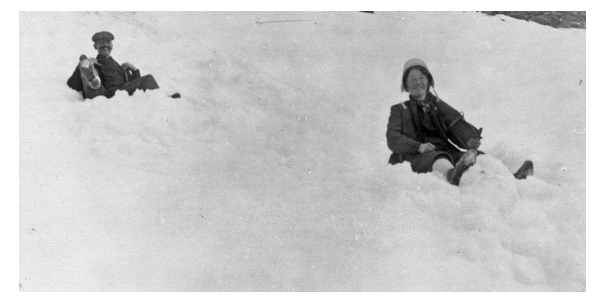




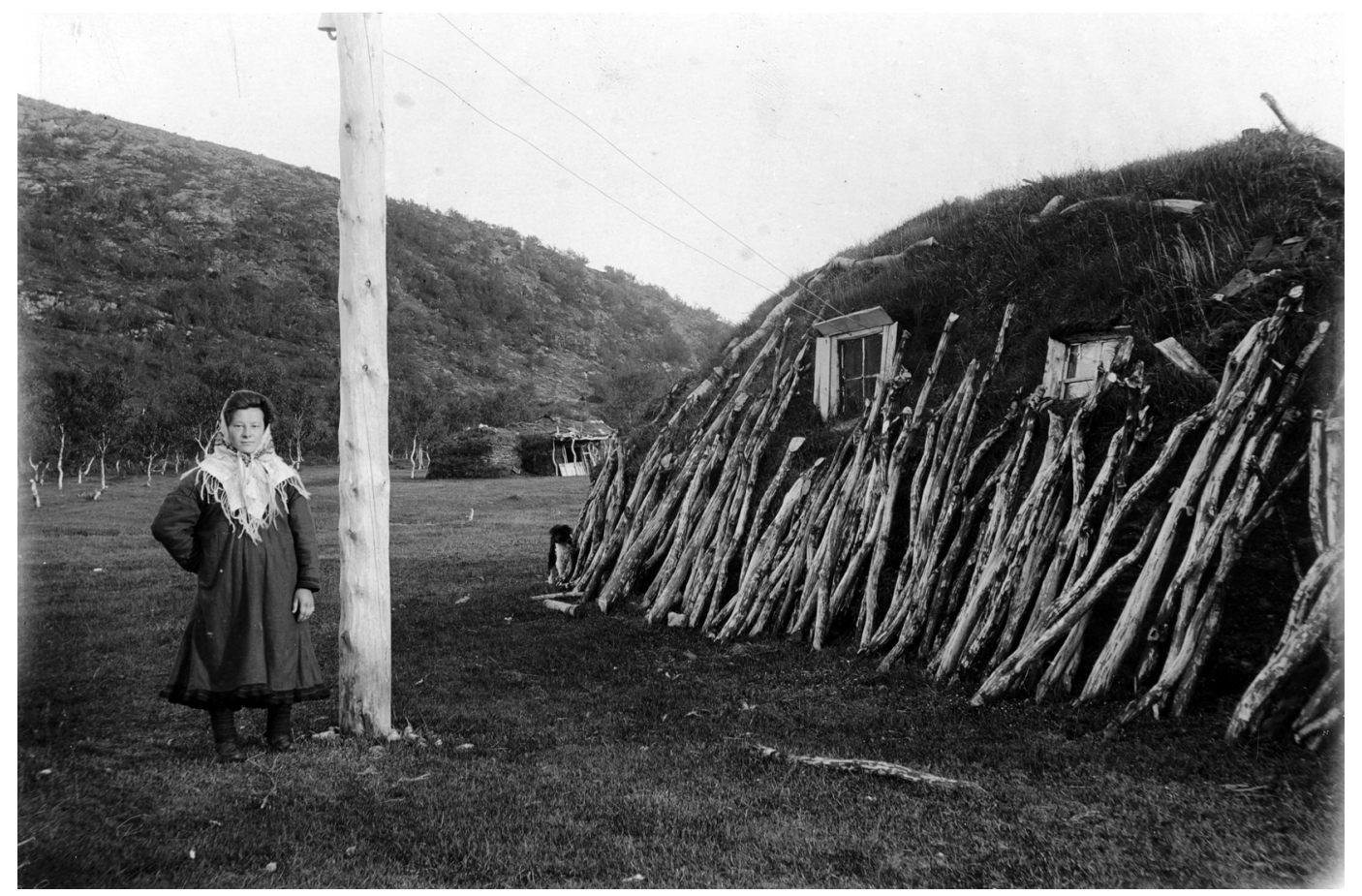

Hanna's photograph of the telephone operator, standing by the telephone exchange, in Lebesby, Finnmark, 1909. (Photo courtesy of the archives of the Norwegian Directorate for Cultural Heritage [Riksantikvarens arkiv].)

After her two stints in Svalbard, Hanna turned her attention to the flora of northern Norway and in 1909 she travelled to Finnmark, the country's northernmost county, located well above the Arctic Circle. At that time Finnmark was seen as almost as remote a location as Svalbard. Finnmark had the added "exotic" element of the indigenous Saami inhabitants, many of whom were reindeer herders and whose language bears no relation to Norwegian. Hanna spent three months there, guided by a local man, sleeping in her tent and surveying the plant life (Resvoll-Holmsen 1917). Thus she spent her the first months of her second marriage: in July, shortly before embarking for Finnmark, Hanna and Gunnar Holmsen had been married in Tromsø. Holmsen was the brother of Thekla's husband, who was also a geologist [Eckblad 1991]). For his part, Holmsen spent his "honeymoon" in Svalbard. The couple had a son, Per, two years later.

Hanna was awarded a Cand. real. degree, approximately equivalent to a Master's degree, in 1910 (Eckblad 1991). (Her sister had also earned one and in 1917 Thekla earned her doctorate with her dissertation, Om planter som passer til kold og kort sommer [Plants adapted to cold, short summers].) Hanna's 
thesis-Observations botanique (it was in French) — was based on her work in Svalbard and was one of Norway's very first botany theses. It was subsequently published in the Prince of Monaco's scientific series on Svalbard. In 1915 Hanna became a research fellow in botany and in 1921 she became Norway's first docent (which equates to a reader in the UK) in plant geography. Svalbards flora, a popularized version of her thesis, was published in 1927. The book was the foundation for handbooks with the same title later put out by the Norwegian Polar Institute. Hanna published a number of more specialized scientific works on alpine and Arctic plants. She was the first in Norway to apply statistical analyses in her studies of plant communities (Christophersen 1943; Eckblad 1991).

Hanna's talents were not limited to science. She was an excellent photographer and was one of the first Norwegian scientists to make use of colour photography, which she first experimented with in Svalbard (Skår 1998). She was also a poet and made up botanical mnemonic rhymes that her students found both enjoyable and useful (Eckblad 1991). Hanna was passionate about nature conservation and championed a number of causes in Norway (Christophersen 1943; Berntsen 1977; Eckblad 1991). In Svalbards flora, she left out mention of particular locations where the plants she described occurred in an effort to protect rare species from being disturbed by curious visitors (1927b: 20). Teaming up with Adolf Hoel, Hanna exerted pressure on the Norwegian government to ensure that adequate conservation measures were undertaken in Svalbard once the archipelago had come under Norwegian suzerainty (Berntsen 1977). They pushed for the complete protection of the north-western part of Spitsbergen as a national park, the protection of vegetation in an even larger area, and the preservation of plants and animals on Bjørnøya (Bear Island), the tiny outlier to the south of the main group of islands.

Hanna died in Oslo in 1943. Like her sister, whose many achievements have only been briefly touched upon here, Hanna has been enormously

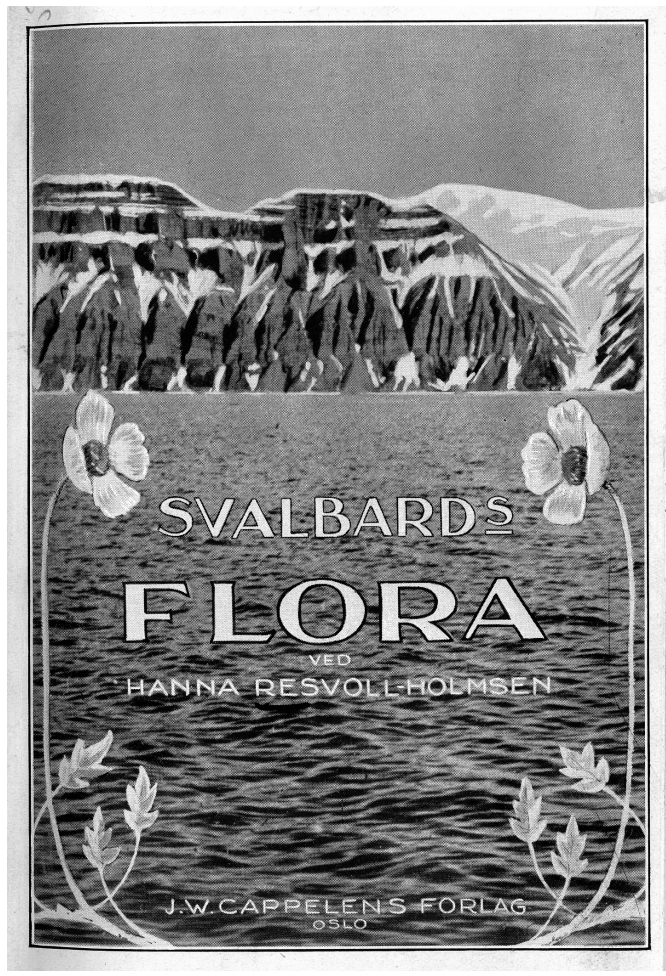




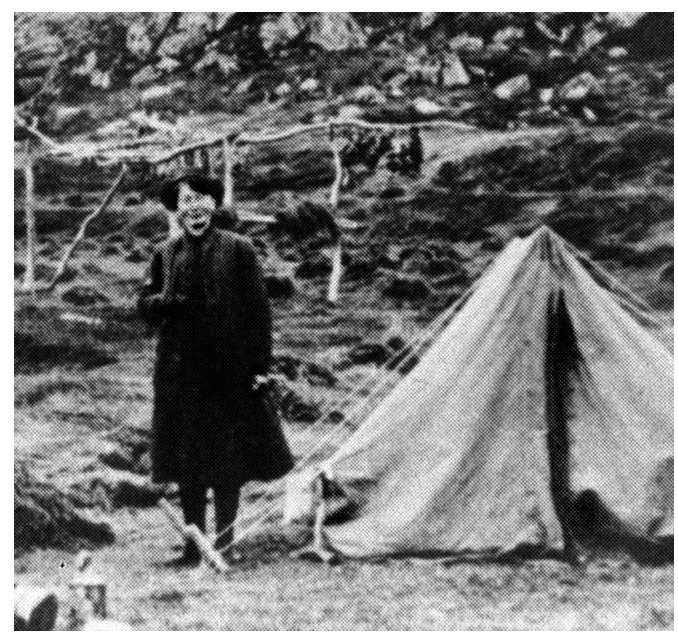

Hanna beside her tent in Laksefjord, Finnmark, 1909. (Photo courtesy of the Norwegian Polar Institute Picture Library.) significant for Norwegian botany and for women in science and academics in Norway. Independent, resourceful, innovative, passionate, analytical and apparently not afraid to break with convention, she pushed forward the boundaries of what it was possible to achieve during her times and paved the way for many who followed.

\section{References}

Barr, S. 1995: Staten, forskingen og Spitsbergentraktaten-om Norsk Polarinstitutts forgjengere før og etter 1920. (The state, research and the Svalbard Treaty-on the Norwegian Polar Institute's predecessors before and after 1920.) In R. Sørheim \& L. J. Johannessen (eds.): Svalbard-fra ingenmannsland til del av Norge. (Svalbard - from no-man's land to part of Norway.) SMU Rapp. 3. Pp. 66-83. Trondheim: Norwegian University of Science and Technology.

Barr, S. 2003: Norway - a consistent polar nation? Oslo: Kolofon.

Berntsen, B. 1977: Naturvernets historie i Norge. (The history of nature conservation in Norway.) Oslo: Grøndahl \& Søns/Norwegian Society for the Conservation of Nature.

Christophersen, E. 1943: Hanna Resvoll-Holmsen (1873-1943). Minnetale holdt på årsmøtet 30. mars 1943. (Hanna Resvoll-Holmsen [1873-1943]. Memorial speech given at the annual meeting, 30 March 1943.) Blyttia 1, 100-102.

Eckblad, F.-E. 1991: Thekla Resvoll og Hanna Resvoll-Holmsen, to glemte?-pionerer i norsk botanikk. (Thekla Resvoll and Hanna Resvoll-Holmsen, two forgotten? pioneers in Norwegian botany.) Blyttia 1, 3-10.

Evjen, B. 1999: Kvinnelige polarforskere-eksotiske innslag, inntrengere eller likemenn? (Women polar researchers-foreign elements, interlopers or peers?) Ottar 3, 31-41.

Norwegian Polar Institute 2005: Prince Albert I of Monaco and Norwegian Arctic Research. Tromsø: Norwegian Polar Institute.

Resvoll-Holmsen, H. 1917: Fra en reise i Finmarken i sommeren 1909. (A trip to Finnmark in the summer of 1909.) In: Den Norske Turistforenings aarbok. Pp. 118-135. Kristiania (Oslo): The Norwegian Mountain Touring Association. 
Resvoll-Holmsen, H. 1927a: Holmsen, Hanna Resvoll. Studentene fra 1902. Biografiske oplysninger samlet til 25-års-jubileet. (Students from 1902. Biographical information collected for the 25th anniversary.) Pp. 166-169. Oslo: Grøndahl \& Søns.

Resvoll-Holmsen, H. 1927b: Svalbards flora. Oslo: J. W. Cappelen.

Royal Ministry of Justice 1988: Treaty of 9 February 1920 relating to Spitsbergen (Svalbard). Act of 17 July 1925 relating to Svalbard. The mining code for Spitsbergen (Svalbard). Oslo: Royal Ministry of Justice.

Schibsted, A. \& Resvoll-Dieset 1998: Sommerliv på Spitsbergen 1908. (Summer life on Spitsbergen, 1908). Svalbardminner 12. Skien: Vågemot Miniforlag.

Skår, A. 2003: Thekla og Hanna Resvoll — to gløymde pionerar. (Thekla and Hanna Resvoll- two forgotten pioneers.) In: Arbok for Gudbrandsdalen 71. Pp. 110-118. Lillehammer: Dølaringen Boklag. 
